\title{
COLOUR REVOLUTIONS, FROZEN CONFLICTS AND THE NEW SILK ROAD: THE POLITICAL STRUGGLE IN THE POST-SOVIET SPACE
}

ABSTRACT As the political centre of the World international stage gravitates toward East Asia, so does the political reality of the Post-Soviet Space. This process works in favour of the Peoples' Republic of China, is a source of new tensions within the Russian Federation and undermines the effectiveness of US and European policies. The New Silk Road and the Asian Infrastructure Investment Bank initiatives show that PRC has both the means and the determination to actively broaden its sphere of influence. However, the Chinese patterns of expansion do not have to follow the nature of Russian-Western competition the World got used to after 1991. As the local players are increasingly assertive and PRC economy is slowing down, it's also important to notice the first clouds gathering over Chinese aspirations in the region. The article presents an overview of the major approaches to political change, international competition and integration trajectories within the Post-Soviet space. It focuses on the major actors active within the Post-Soviet Space, namely the Russian Federation, the United States and the Peoples' Republic of China, the strategies they follow, mediums they choose to execute their strategies and an evaluation of effects of their activity after the collapse of the USSR.

Keywords: Colour Revolutions, Frozen Conflicts, New Silk Road, Post-Soviet Space 


\section{INTRODUCTION}

The Russian Federation's military action in Ukraine, the following occupation and annexation of Crimea in March 2014 have all started probably the gravest security crisis in Europe since the end of the Cold War. The impression was strengthened by other rivalries storming back the centre stage of contemporary international relations, in particular the silent clash of the rising People's Republic of China with the United States of America. Many political analysts reacted with fears of global order being again reduced to Cold War style power Politics. ${ }^{1}$ They raised questions whether the 2014 will be perceived as the mark of the end of post-Cold War stability, if the West was living in the false sense of security about Russian revisionism or may the annexation of Crimea be treated as a sign of rise of revisionist powers, especially Russia and China?

As the saying goes, history does not repeat itself but it rhymes. At the beginning of 1990s, the World was taken by surprise with the collapse of the Soviet Union. The surprise gave birth to triumphant prognosis of the end of history and the victory of the Western marriage of free market economy and liberal democracy. The new century amazed the international community with colour revolutions in the former Soviet republics. As they spread from former Yugoslavia to Georgia, Ukraine and even far away Kyrgyzstan, democratic enthusiasts saw them as a sign of inevitable democratization of the Post-Soviet space. Today many are startled again, yet with events of different nature: the comeback of power Politics at the very border of European Union. Many Western political scientists, especially representing liberal theoretical approaches to international relations, expected the old-fashioned geopolitics go away with the collapse of USSR. ${ }^{2}$ Now the advocates of liberal World Order are shocked with blunt moves of President Vladimir Putin. ${ }^{3}$ They are accused of misreading what dissolution of the Soviet Union meant. ${ }^{4}$ It was an important victory of liberal democracy over communism but it was not the end of Power Politics, their critics say. The scientists more inclined to take a realist approach to international relations foretell the rise of revisionist powers and the comeback of increasingly fierce international competition which marks the end of the post-Cold War stability. ${ }^{5}$

To paraphrase the words of T.S. Kuhn what we see depends not only on what we are looking at but also on what we have learned to notice. ${ }^{6}$ The problem of the perspectives presented above is that quite often they say more about expectations of those who

W.R. Mead, 'The Return of Geopolitics', Foreign Affairs, Vol. 93, No. 3 (2014), pp. 69-79.

2 J. Mankoff, 'Russias Latest Land Grab', Foreign Affairs, Vol. 93, No. 3 (2014), pp. 60-68.

G.J. Ikenberry, 'The Illusion of Geopolitics', Foreign Affairs, Vol. 93, No. 3 (2014), pp. 80-90.

A. Wilson, Ukraine Crisis. What It Means for the West, New Haven 2014, pp. 144-160.

For an overview of the contemporary discussions concerning the interpretations of the dissolution of the Soviet Union: J. Mankoff, Russian Foreign Policy. The Return of Great Power Politics, Lanham 2011, pp. 241-293.

6 T.S. Kuhn, The Structure of Scientific Revolutions, Chicago 1996, p. 180 (International Encyclopedia of Unified Science, 2, 2). 
follow them than about the reality of the Post-Soviet space, which seems to be oversimplified when analysed in purely Western terms. On the one hand, liberal theorists and enthusiasts of democratization underestimated the vitality of the post-communist heritage and patrimonial frameworks still present in former Soviet states. The path of political change and the integration patterns known from Western World proved to be ineffective when dealing with both Yeltsin's and Putin's Russia. On the other hand, realists seem to not notice the fact that the World in 2014 is significantly different from the bipolar reality of the Cold War. The alleged revisionist powers are tightly intertwined in increasingly multilateral international relations order developed during twenty five years that have passed since the collapse of the USSR. And both groups seem to not notice the realities of the Post-Soviet space.

The aim of the article is to present an analysis of major approaches to political change, international competition and integration trajectories within the contemporary Post-Soviet space. To adequately address the problem one has to look at geopolitics within the Soviet Union, analyse how it influences the Post-Soviet reality and how it was challenged by the American and Chinese political strategies since the collapse of the USSR as well as how post-communist heritage was exploited by new Post-Soviet republics. The dynamics of interaction between the major players and their dominant strategies will be analysed on the basis of the most politically expressive developments, like frozen conflicts, colour revolutions and the most recent Chinese economic projects like Asian Infrastructure Investment Bank (AIIB), the New Silk Road diplomacy and One Belt One Road initiative.

The article will argue that the Post-Soviet Space represents a case were big international players such as Russia, US and China exert their influence through various means with Russia aspiring to win back its historical position in the region while China and US formulate their actions as a function of global politics rather than a competition for a regional dominance. This assumption requires further elaboration, though. First, the reality of former Soviet Union and mostly trilateral Great Power competition periodically created circumstances which made the agendas of the Great Powers not entirely exclusive. Secondly, in certain situations the complex circumstances empowered the smaller players - the new independent Post-Soviet republics - giving them opportunities to exploit the Great Powers' engagement for their own ends. Third, the major crises that occurred in the Post-Soviet region after 1991 and had shaken the international community were mostly an effect of a difference between the way the Post-Soviet Space politics is perceived by the Russian Federation (in terms of paternalistically preserving own hegemonic status) and by other Powers (as a function of other regional goals like stability of Xinjiang in case of China or Afghanistan and Southern Caucasus in case of US). In effect the situation in the Post-Soviet space today is an emanation of situational power balance rather than of one dominant political process like democratization or authoritarian turn. Thus, it is far more important to reconstruct the major tendencies that shape this balance than to squeeze the region into one theoretical framework that makes way for future surprises rather than explains the political reality beyond the eastern border of the European Union. 


\section{RUSSIAN FEDERATION, FROZEN CONFLICTS AND POST-SOVIET GEOPOLITICS' HERITAGE}

Frozen conflicts are the best emanation of the dominant Russian strategy in the PostSoviet Space. They epitomize Russian perceptions, ambitions and modes of thought in regards to the region. However, as they are deeply rooted in geopolitics of Soviet times, it's impossible to fully comprehend their nature without taking a step back in history and analysing the heritage of Soviet times. As such they will also act as an introduction to the other Post-Soviet developments.

Describing the Soviet Union geopolitics in detail is a task beyond the scope of a single article, probably even of a single monograph. Nevertheless, in the context of 2014 events in Ukraine it is possible to define several characteristics of geopolitical developments within USSR which had outlasted the Soviet Union, had formed fundaments for the development of the crisis the World witnessed in Crimea and still shape frozen conflicts in the Post-Soviet space. Soviet Union should not be perceived only in political terms. It was not only political but also social and economic project. As the political dimension is perceived from the perspective of the collapse of the Eastern Block, it is important to notice that to a large extent social and economic heritage of the Soviet Union outlived the USSR. The frozen conflicts are one of the best proofs.

The most important elements of Soviet heritage in terms of frozen conflicts include: (1) the existence of significant ethnic minorities protected by Moscow within each Soviet Republic, (2) the universal presence of Russian minority, which was the spearhead of Soviet modernization in all non-Russian Soviet Republics and (3) managing and orienting economic and infrastructural development of all Soviet Republics in a way making them dependent on Russia.

According to the official communist ideology of USSR, nationalism was condemned to gradually fade away along with the development of the class solidarity which was to be popularized by the revolutionary march of the Red Army to the West. When the Soviets were stopped in Poland in 1920, the leaders of the communist state had to deal with a mixture of nationalities within their own borders. A solution was a peculiar form of federalism according to which major ethnic groups within the Union were assigned separate territorial units. Eventually, between 1922 and 1940 fifteen Soviet Socialist Republics (SSRs) were created. In 1991 they became independent states. ${ }^{7}$

The major requirement for an ethnic group to be attributed a territorial unit - a Socialist Republic - was to consist over 50\% of its population. As the Soviet Union's population was diverse, it was natural that numerous nationalities were representing significant majorities on their historic lands. However, because of natural as well as centrally managed migrations, each of the SSRs contained significant minority groups, which often enjoyed their own statehood in other parts of the USSR. ${ }^{8}$ For example in Cauca-

More on nationalism and administrative development of USSR: R. Suny, The Revenge of the Past. $\mathrm{Na}$ tionalism, Revolution, and the Collapse of the Soviet Union, Chicago 1993.

8 More on politically forced migrations in USSR: P. Polian, Against Their Will. The History and Geography of Forced Migrations in the USSR, Budapest 2003. Ukrainian context: A. Reid, Borderland. A Journey through the History of Ukraine, Boulder 2000. 
sus there was a large Armenian minority in Azeri SSR, as well as a large Azeri one in Armenian SSR. In Central Asia Uzbeks were significant ethnic factor in the neighbouring Kazak and Kyrgyz SSRs (to a lesser degree they were also present in Tajikistan and Turkmenistan). To make situation even more complex the borders were often delineated across ethnic groups' historical territories, which resulted in development of small autonomous enclaves within many SSRs. The most prominent examples are Abkhazia and Southern Ossetia in Georgia, and Nagorno-Karabakh in Azerbaijan.

The ethnic diversity created in this way was no coincidence. The goal was twofold. First, a significant presence of concentrated minorities within mainly ethnically defined SSR was to provide the USSR central government with leverage against national majorities' mobilization against Moscow. Kremlin was able to play out the ethnic groups against one another and thus to stop them from disobeying central Soviet Union authorities. Second, it created an image of Russia as a protector and guardian of interests of ethnic minorities within USSR, providing Moscow with their sometimes unconditional support.

The strategy of ethnic division and economic subordination worked well for Kremlin. The best proof is the fact that during the 1980s, most of the minority groups mentioned opposed the nationalist movements that were pressing for independence in many of the Soviet republics as Gorbachev's Perestroika and Glasnost politics started to ease the rule of Moscow over the rest of the empire. All the minorities viewed the survival of the Soviet Union as the best guarantee of their protection against the larger ethnic groups that surrounded them. For example, officials representing Abkhazia, South Ossetia and Transnistria supported the August 1991 coup, which they believed was to save the Soviet Union from collapsing.?

Apart from the above mentioned minorities, which were usually linked to a neighbouring SSR and did not constitute a significant presence in other parts of the Soviet Union, there was also one specific minority present universally all over the USSR Russians. The role they played in Soviet geopolitics was different from other ones, though. Usually they filled the higher levels of Soviet Republics' bureaucracies, higher ranks of military corps and often they formed the core of the better educated part of the society providing many parts of the USSR with the only source of technical knowledge. This way they represented the fore of the Soviet style modernization and industrialization as well as provided Moscow with practical means of control of all of the parts of the USSR.

The Russian ethnic management of the Union was supplemented with very specific economic development trajectories of the SSR republics. If one analyses the infrastructural development of Central Asian, Caucasian and Western Republics of the Soviet Union, one will easily notice that most of the transport infrastructure, like roads, railways or pipelines, was oriented either towards Russia or according to Russian interests. With other venues for economic development closed, and echelons of power and of

9 For background of these events: R. Keeran, T. Kenny, Socialism Betrayed. Behind the Collapse of the Soviet Union, New York 2010; R. Strayer, Why Did the Soviet Union Collapse? Understanding Historical Change, London 1998. 
economic management dominated by Russians this strategy made all the SSRs virtually dependent on Moscow economic plans. Regardless how much is said today about national issues within individual SSRs, it has to be remembered that the economy of the USSR was coordinated from Moscow and according to its needs. ${ }^{10}$

Soviet politics concerning minorities is central to the all frozen conflicts within the former USSR. The changes of political maps after the dissolution of USSR in 1991 created an impression that Russia's sphere of influence shrunk more than it actually happened. Russia was not gone not only from the Post-Soviet space but also from the PostSoviet states' internal scene. With not much of an oversimplification from the Russian perspective the only difference between Soviet and Post-Soviet times was that now the ethnic conflicts which were previously used by Moscow to win one ethnic group against another became a part of the foreign rather than internal politics of Kremlin. Russian presence in higher echelons of bureaucracies of all of the Soviet States provided Moscow with detailed information concerning internal relations and political situation within each of the Post-Soviet States. ${ }^{11}$ This, combined with dependence on Russian economy and large military potential allowed the Russian Federation to exploit and intensify the moments of instability to create situations justifying interventions to protect threatened ethnic minorities from ethnic cleansing. However, not a single Russian intervention led to a constructive solution of any conflict that was its cause. Instead frozen conflicts were born. On the one hand Russia suppressed the tensions well enough to keep peace on troubled territories, while on the other hand it used the threat of their resurfacing to keep military presence and to exercise political pressure on states going through ethnic crisis.

Since the early 1990s, Russian Federation has either directly supported or significantly contributed to the development of four breakaway ethnic regions in Post-Soviet Space. The first one, Transnistria, is a self-declared state in Moldova on the western border of Ukraine. The second and third one, Abkhazia and South Ossetia, located in the Northern and Central part of the Russia-Georgia borderline respectively, at the beginning were semi-autonomous regions protected by Russian military presence. After the Georgian - Russian war in 2008 both declared independence which was recognized by Moscow. The last one, Nagorno-Karabakh, is a region in south-western Azerbaijan that declared independence under Armenian protection following an Armenian - Azerbaijan war in the 1990s. Despite being an effect of Armenian - Azerbaijan conflict, its existence is guaranteed by the local presence of Russian military forces. As a result of each of these frozen conflicts the splinter territories remain beyond the control of the central

10 More and more often political scientists point out that actually some parts of USSR may have been exploiting Russia to a larger extent than Russia was exploiting them. However, in context of the article it is important to emphasize the dependency of economic development patterns on Moscow. For the mentioned views check: K. Collins, Clan Politics and Regime Transition in Central Asia, Cambridge 2006, pp. 102-134.

11 Personal and social links between Russian Federation and Post-Soviet states that survived 1991 are even more important in context of large shadow economy and rampage corruption that plagued almost all of them. Informal connections gave Russians an information advantage that was beyond the reach of any other actor in the Post-Soviet space. 
governments and the local de facto authorities enjoy Russian protection but also exert Russian influence.

In this context, Russia's invasion of Crimea up to a certain moment was a replay, and after a certain moment became an escalation of tactics that Kremlin has used for the past two decades to maintain its influence across the domains of the former Soviet Union. This moment was marked by the decision to incorporate the peninsula into the Russian Federation. Until Russia annexed Crimea, the situation in Ukraine had been played out by Moscow according to an earlier known script. Russia supported ethnic tensions and applied limited pressure during a period of political instability, before endorsing territorial revisions that allow it to obtain a foothold in the contested region. By committing itself to the annexation, Russia has changed the scenario, though. Even in cases of radically pro-Russian self-proclaimed republics of South Ossetia and of Abkhazia it did not decide to take over their territories and to annex them to the Russian Federation. This raises a question regarding the factors that pushed Russia to abandon the earlier strategy and to go further in Crimea.

\section{WESTERN EXPANSION, COLOUR REVOLUTIONS AND THE RISE OF LOCAL PLAYERS}

When in 1991 USSR was replaced with 15 new independent states, the change of international and political reality did not mean that the problems of the Soviet times were gone. As far as ethnic minorities, Russian presence and the economic dependence on Moscow were concerned, the reality of the Post-Soviet states did not change much. One can say, that political change: the dissolution of the Soviet Union and emergence of Post-Soviet states, outpaced social and economic change, which required to be addressed in a new reality of multilateral international politics instead of one unilaterally dominated by Russia. As a result, all the tensions managed by Soviet authorities were forcefully brought back to light.

As the Soviet Union dissolved, many of the national divisions that were earlier managed by Moscow sparked a wide range of internal problems. Ethnic tensions, which reemerged after 1991, led to outbursts of violence and eventually local wars in Georgia, Moldova and Azerbaijan. To a certain extent one can place the ethnic clashes between Kyrgyz and Uzbeks in Kyrgyzstan and the civil war in Tajikistan in the same category. New Post-Soviet states had to face both the new reality of multilateral international politics and the old internal ethnic tensions which were superficially suppressed but never truly solved under the Soviet rule. With Soviet Union gone they have dramatically resurfaced and demanded solution from the young, inexperienced and relatively weak states.

However, at the same moment the Post-Soviet space, for the first time since the 1920 s, became an arena of international competition for power and influence. Instead of one dominant player - Russia, there were many actors interested in widening their spheres of influence. The US was trying to develop its economic presence in oil and gas 
rich regions. The European Union and NATO were looking to expand eastwards. China was quietly but steadily increasing its presence in neighbouring Post-Soviet states.

In economic dimension this has meant slow but on-going diversification of PostSoviet states' markets from mostly Russia-oriented to more interdependent ones. The catastrophic economic situation did not allow realizing the diversification strategy quickly. Nevertheless, the introduction of new foreign actors was often used by local states to diminish existing Russian influence and to reorient their economies as well as policies in a way making them less dependent on Moscow. Thus, for example Georgia, Ukraine and Moldova started to look for alignment with the West. Some Central Asian states, like Kazakhstan, Kyrgyzstan and Uzbekistan, were trying to balance Western, Russian and Chinese ambitions to maximize own capabilities in international relations. ${ }^{12}$ While taking into account that the political moves of the new states were not always consequent, the new foreign actors became important factors in their internal politics. Eventually, especially in cases of colour revolutions, they became an effective counterweight to Russian regional presence.

Just like the frozen conflicts are an emanation of Russian push to regain the position lost in 1991, the colour revolutions are a direct consequence of Western expansion to the Post-Soviet space. Rose Revolution in Georgia in 2003, Orange Revolution in Ukraine in 2004 and Tulip Revolution in Kyrgyzstan in 2005 have shown that the Post-Soviet space was not an arena of solely Russian power play anymore. The enthusiasts of Western-like democracy saw their eruption as a third wave of democratization and a success of demo-liberal model of society. The critics saw the revolutionary events as inspired by foreign forces and as instrumentally aimed against the Russian dominance in the region. The most striking aspect of the debates is the fact of incredible ease of defining revolutions as anti-Russian or pro-Western. It is also symptomatic that democratic interpretations appear almost exclusively in Western languages, while the critique of colour revolutions is most often conducted in Russian.

This tendency proved to be a long lasting one. As the time passed it became obvious that not a single case of colour revolution led to a political systemic change of revolutionary character. The disappointing reality was covered up by spontaneous social upheaval. The social instability led to a situation when both, the supporters and the critics were concentrating on what was going in the Georgian, Ukrainian and Kyrgyz streets rather than in the broader picture. And again both sides - the supporters and the critics - saw the evolution of events differently. The enthusiasts were disappointed with the inability of the revolutionary elites to conduct a real change. The critics were

12 For example, Kazakhstan already in the second half of the 1990s got involved in development of alternative routes of oil exports from Central Asia through Baku-Tbilisi-Ceyhan (BTC) pipeline supported by US, after 2005 also through another oil pipeline to China; Uzbekistan until 2005 provided US with the first military base in Central Asia; Kyrgyzstan, until 2005 was perceived as "an island of democracy" in the region and attracted Western financial aid as well as provided US and NATO with military base almost a decade longer than Tashkent. More on Central Asian politics of balancing between Russia, PRC and US: K. Kozłowski, Państwo Środka a Nowy Jedwabny Szlak. Poradziecka Azja Centralna i Xinjiang w polityce CHRL [Middle Kingdom and the New Silk Road: the Post Soviet Central Asia and Xinjiang in PRC Politics], Torun 2011 (Biblioteka Azji i Pacyfiku). 
unable to accept the strength of civil society and the existence of social movements that actually may act outside of official regime's political frame.

In the world of politics interpretations sometimes tell more than facts. Interpretations of colour revolutions tell a lot about the political situation and rivalry in the postSoviet space. As the colour revolution erupted, the post-Soviet space became an arena of competition between two dominant models of expansion - Russian and American one. The Russian Federation was using its historic, economic and social links with the post-Soviet states and own experiences in relations with its close neighbours to actively block foreign influence close to own borders. The United States and the EU were using soft power to promote Western democratic and economic model. The Russian Federation was trying to take advantage of the post-Soviet heritage - frozen conflicts close to its borders - and still based on hard power (wars in Georgia and Chechnya, Armenian Azerbaijan conflict, Central Asian states' instability, Crimea ethnic profile), while the Western side was promoting a certain style of life and social order based on Western values. It has to be admitted that Russia effectively uses its political and economic assets to retake its geostrategic position lost at the break of the 1980s and 90s. It is also hard not to admit that in that sense post-Cold War globalization in 1990s worked in favour of the West. ${ }^{13}$ The West was significantly involved in supporting the organizers of colour revolutions, in overthrowing usually Russian friendly government and in supporting revolutionary politicians during the introductory periods of their rule. Just like Russia supported presidents Eduard Shevardnadze in Georgia, Leonid Kuchma in Ukraine and Askar Akayev in Kyrgyzstan, the US foundations closely connected to two major US parties supported the opposition in each of these countries. And despite the fact, that from democratic states' perspective such an intervention in Georgian, Ukrainian or Kyrgyz affairs was justified, it still was a significant intervention in a region of prominent importance for Moscow and an important step against Russian geopolitical interests. ${ }^{14}$

In the meantime, colour revolutions were one of the first signs of new actors arising in the Post-Soviet space. The political confrontation between Russia and the West created a new international context for the local regimes. The complex geopolitical situation (the American-Russian confrontation) combined with the challenges of transformation (economic and social crisis after the collapse of USSR) which all the post-Soviet states had to face at the beginning of 1990s, forced them to look for a path that combines appeasing Great Powers and achieving some sort of political independence and

13 Of course the general assumptions evolved differently in different parts of former Soviet Union but still followed the same trajectory, comp.: T. Stępniewski, 'The Place of Central Asia in Poland's Foreign Policy', Roczniki Nauk Spotecznych KUL, Vol. 7 (43), No. 1 (2015), pp. 11-22; idem, 'Region Morza Czarnego w polityce Unii Europejskiej i Stanów Zjednoczonych Ameryki w XXI wieku’ in J.M. Fiszer, P. Olszewski (eds.), System euroatlantycki w wielobiegunowym tadzie międzynarodowym, Warszawa 2013, pp. 163-180 (System Euroatlantycki w Wielobiegunowym Świecie i Jego Perspektywy, 6).

14 Comp. T.G. Ash, T. Snyder, 'The Orange Revolution', New York Review of Books, 28 April 2005, at <http://www.nybooks.com/articles/archives/2005/apr/28/the-orange-revolution/>, 14 September 2015; С. Кара-Мурза, Народное хозяйство СССР, Москва 2012. 
security. All the new leaders of post-Soviet countries were doing whatever they could to win support of the foreign actors to gain more freedom in the domestic field, even if it meant domestic decrease of social support. ${ }^{15}$

In the above context, the colour revolutions seem to be a political vehicle used to renegotiate the choices made by the first independent elites of the post-Soviet states in the 1990s. It does not mean a democratic change, though. It means a change of ruling elites and winning foreign support on the basis of the social explosion against those who were ruling since 1991. It means looking for a way to fit in the post-Soviet map which was to a large extent drawn by Moscow and Washington. The revolutionary interpretation of the events discussed is useful for all the actors involved. For the new elites it is useful as a form of legitimacy of an apparently new regime that abruptly severed its ties with the socially unpopular past. It is also a perfect tool to fill the international void left after the collapse of the former political regimes. For the West it seems to be a democratic success. For the Russian Federation it is a legitimate reason to fight back. ${ }^{16}$ However, the instability visible throughout the next decade shows that it was too early to say that the region has been transformed according to the liking of any of the actors mentioned above. It still remains a post-socialist collage, shaped by the dreams of independent past mixed with still strong socialist heritage and adapted Western institutional solutions.

Colour revolutions have shown that geopolitical processes that have been developing in the post-Soviet space and that shape the reality of the region often remain hidden from the eyes of the outside observers. Not less important is the international context of the events. The revolutions are strongly shaped by geopolitical competition between US and Russian Federation, while other post-cold war powers, like PRC, were still not fully active in the region. They concern not only political issues. In most cases their consequences sent tremors through energy markets and raised questions concerning the intervention in defence of human rights. These experiences will shape the international politics for years to come.

The most important consequence of the colour revolutions in the post-Soviet space will be acknowledging that research instruments that work well in the Western World may not be best suited for studies concerning other areas of the globe. Defining the colour revolutions in straightforward terms of pro-democratic change has proven to be too superficial. It does not only involve wrong assessment of the events but also puts Western aid and financial support for democratization processes in danger of being exploited in processes that have little to do with democratization. Social mobilization witnessed in all the countries that experienced colour revolutions creates an opportunity for greater involvement of citizens in political processes. However, it does not

15 An easy analogy may be drawn to the Soviet times when the conformity to Moscow was the measure of political opportunities granted to local communist regimes. The same factor seems also characteristic for the later process of East European states joining European Union.

16 For a list of new restrictions on NGOs and media introduced after color revolutions in Russia and other Post-Soviet states: A. Cooley, Great Games, Local Rules. The New Great Power Contest in Central Asia, New York 2012, pp. 179-184. 
preclude the form of the involvement. It does not mean inevitable democratization. Actually, the revolutionary wave unveiled mechanisms that are closer to reorganization of existing political elites than to a true systemic change. One can speak of adaptation to changing international environment without actually changing the domestic political system. The common elements of the events (evolution form economic to political demands, mass protests of mostly young people, demands for greater freedom of civil society) should not cover up regional differences, complex domestic contexts and the most important fact that in most cases the true political alternative to existing political elites was lacking. It seems that more time is needed for a genuine political change to occur. And maybe it's not the actual goal of the regimes in the region.

\section{CHINA'S RISE, THE NEW SILK ROAD AND THE FUTURE POST-SOVIET CHALLENGES}

Despite the political storms over colour revolutions, the history has shown that Russia's strongest competitor for regional influence came not from the West but from the East. China's growing role in the Post-Soviet space is nothing short of remarkable, though in regional context it's less frequently commented than the Russian-American competition. ${ }^{17}$

China engaged with the region with the primary aim of stabilizing its own adjacent territory - Xinjiang, and of controlling activities of potentially separatist Uyghur groups. Thus, geopolitically, Chinese attention was focused mostly on Post-Soviet Central Asia. PRC did not enjoy the advantage of local connections, as it was in the case of Russia, nor global scope of action, as it was in the case of the US. Nevertheless, Beijing proved to be the most nuanced and skilled of the players in, as Prime Minister Li Peng put it in his speech in 1994 in Astana, New Silk Road diplomacy. ${ }^{18}$

China was slowly but steadily developing the foundations for its future activity via two parallel routes. ${ }^{19}$ First, PRC tailored its engagement with each of Central Asian countries. In Kyrgyzstan, for a long time the only fellow WTO member in Central Asia, it established major and re-export hub to the rest of the region. In Tajikistan it focused on upgrading electricity and transport infrastructure. In Kazakhstan and Turkmenistan it managed to develop energy partnerships and build new oil and gas pipelines. Secondly, it has introduced multilateral platform of cooperation in the region - the Shanghai Five and later the Shanghai Cooperation Organization (SCO). The strategy was based on promoting win-win scenarios and on non-interference in domestic affairs, while reassuring Russia that China harbours no hegemonic ambitions. ${ }^{20}$

\footnotetext{
17 More: E.S. Medeiros, China's International Behavior: Activism, Opportunism and Diversification, Santa Monica 2009, pp. 101-110 (Rand Corporation Monograph Series).

18 H.H. Karrar, The New Silk Road Diplomacy. China's Central Asian Foreign Policy since the Cold War, Vancouver 2009, p. 61 (Contemporary Chinese Studies).

19 M. Lanteigne, Chinese Foreign Policy. An Introduction, London 2009, pp. 150-153.

20 Z.Zhu, China's New Diplomacy. Rationale, Strategies and Significance, Burlington 2010, pp. 111-139.
} 
The political and economic calculation was simple. If PRC got involved in security issues in the Central Asia or more broadly in the Post-Soviet space, it would mean a confrontation with Washington or Moscow and a relocation of large political and economic potential needed elsewhere, especially in Chinese economy. If it succeeds, the economic development should translate into stability of the region, thus keeping the costs of regional security low, as well as erode Russian and American influence, based largely on military strength. Thus, China has preferred to free-ride the Russian and American involvement in maintaining regional security to minimize costs of own involvement in issues regarding regional stability and to develop a complex web of economic interconnections in the region..$^{21}$ The approach turned out to be successful. Post-Soviet Central Asian states were eagerly developing increasingly sophisticated economic and political relations with China without any serious setbacks, as it was the case in their relations with the US or Russia. ${ }^{22}$ While the US or Russian regional potential was fluctuating - in American case in Afghan war, in Russian in Georgian war context - the regional potential of China is continuously growing.

China's main vehicle of the New Silk Road diplomacy was the new multilateral organization - SCO. The success of Shanghai Five, a forum which facilitated negotiations between China, Russia, Kazakhstan, Kyrgyzstan and Tajikistan over unsolved border issues, prompted its members to develop the dialog mechanism further. After accession of Uzbekistan in 2001 it took shape of Shanghai Cooperation Organization. Originally it was established as a forum for fostering regional security cooperation. Members of SCO emphasize that it was the very first international organization of 21 century designed to combat terrorism and organized crime or in Organization's nomenclature the three evils: terrorism, separatism and extremism. ${ }^{23}$ The organization has also launched a number of non-security initiatives in the areas of economic cooperation, education, development and project financing. Beijing agenda, resources and diplomatic energy have been the driving force behind its evolution from the very beginning, though.

21 M. Lanteigne, China and International Institutions. Alternative Paths to Global Power, New York 2005, pp. 115-142 (Asian Security Studies).

22 It does not mean that China was abstaining from military cooperation. On October 11-12, 2002, China and Kyrgyzstan conducted the first joined military exercises. These were the first such military exercises conducted by People's Liberation Army. Scenario was based on countering a potential sudden terrorist attack. In August 2003 all member states of SCO took part in another joint military exercises. During these operations US troops were already present on Kyrgyzstan and Uzbekistan territory. However, US observers were not invited to take part in the exercises. Since then the SCO military exercises, within so called Peace Mission framework, take place more or less once per two years. 'China, Kyrgyzstan Hold Joint Anti-Terrorism Exercise 10-11 October', Xinhua, 11 October 2002; 'China, Kyrgyzstan Plan Large-Scale Anti-Terrorism Exercise', AFP, 16 September 2002; 'SCO to Hold Military Exercise on Fight Against Terrorism Late August', ITAR-TASS, 27 May 2003; 'Peace Mission 2007', People's Daily, at <http://english.people.com.cn/90002/91620/index.html>, 14 September 2015.

23 The founding Declaration of Shanghai Cooperation Organization, was signed on June 15, 2001, just three months before September 11. T.N. Marketos, China's Energy Geopolitics. The Shanghai Cooperation Organization and Central Asia, Milton Park 2010, pp. 31-66 (Routledge Contemporary China Series). 
The evaluation of Chinese political strategy should not be one dimensional, though. Western scholars have noted that Beijing has demonstrated a willingness to play by international rules and even to be socialized into accepting the security norms embodied in major international treaties and regimes. ${ }^{24}$ In this context, PRC politics in Central Asia could be treated as a case study of Chinese international politics. It exemplifies how historical experiences and on-going perception of the international environment influences the political goals of the Middle Kingdom. The complexity of the situation in the region made the Chinese authorities employ a vast array of political instruments offered by post-Cold War globalizing reality of international relations. The SCO seemed to take the issue further, as it was China's first major attempt to establish a genuinely new international organization. The result is that Beijing has a considerable and growing stake in its success, which, in turn, leads it to play up its accomplishments as a multilateral forum. As a result, even in cases in which the SCO as an organization has not advanced a common policy or adopted Beijing's proposals, PRC has continued to refer to its bilateral engagements with the Central Asian states as $S C O$ projects and initiatives. ${ }^{25}$ Such labelling causes confusion in terms of attribution of Chinese accomplishments to the SCO regional mechanisms. This "credit attribution" of bilateral agreements to the SCO has been a recurring theme in the organization's public image and promotion. ${ }^{26}$ It is also noteworthy that the Organization became an arena of the first political tensions between the Russian Federation and the PRC. ${ }^{27}$

Nevertheless, the idea of the New Silk Road did not lose its impetus. To the contrary it gained momentum as $\mathrm{Xi}$ Jinping declared another step in its realization: One Belt One Road initiative. ${ }^{28}$ Although its details vary by map to map and proposal to proposal, generally, the overland road, comprising transport, energy and telecommunication infrastructure is designed to link China, Central Asia, the Middle East and Europe. The maritime belt would stretch from China's coast through the South China Sea, the Indian Ocean, and the Red Sea to the Mediterranean Sea. The initiative will be co-funded by AIIB, the New Silk Road Fund and the New Development Bank initiative between BRICS nations. China's leader calculated that the initiative will concern 4.4 billion people in more than 65 countries, and that annual trade with participant nations may climb to $\$ 2.5$ trillion within next decade. If successful, the ambitious

24 The core argument in: A. Kent, Beyond Compliance. China, International Organizations and Global Security, Stanford 2007 (Studies in Asian Security).

25 N. Kassenova, 'China as an Emerging Donor in Tajikistan and Kyrgyzstan', Russie.Nei.Vissions, No. 36 (2009), at <http://www.ifri.org/en/publications/enotes/russieneivisions/china-emerging-donor-ta jikistan-and-kyrgyzstan>, 14 September 2015.

26 The perception of SCO as a critically important factor in resolving border issues remains at the foundational core of the organization and its official history. But as Central Asians caution it would not be accurate to one dimensionally ascribe the security cooperation to SCO. G. Gavrilis, The Dynamics of Interstate Boundaries, New York 2008, p. 123 (Cambridge Studies in Comparative Politics).

27 'Sino-Russian Split at Regional Summit', The Asia Times, 15 November 2007, at <http://www.atimes. com/atimes/China/IK16Ad01.html>, 14 September 2015.

28 Chinese President Xi Jinping officially announced the "belt" in a September 2013 speech in Kazakhstan and the "road" in his speech in Indonesia, one month later. 
program would make China a principal economic and probably political force in Eurasian integration as it calls for increased diplomatic coordination, standardized and linked trade facilities, free trade zones and other trade facilitation policies, financial integration promoting the renminbi, and people-to-people cultural education programs throughout nations in Asia, Europe, the Middle East, and Africa. Some have characterized it as China's Marshall Plan, but Chinese leaders reject the comparison. ${ }^{29}$ However, most of the commentators call it the most significant and far-reaching project the nation has ever put forward. ${ }^{30}$

As far as the political logic, the initiative is a continuation of earlier approaches rather than a genuine innovation, though. The One Belt, One Road strategy still treats international environment, including Post-Soviet space, as a function of several domestic goals China plans to advance. First, it is supporting the Chinese economy by providing an outlet for excess industrial capacity. As the new Chinese norm of slowing GDP growth gets introduced, PRC authorities need to cool down the overheated infrastructure sector. One Belt One Road plans involve channelling investment-led growth beyond PRC borders, while assisting the relatively underdeveloped western and southern Chinese regions. Second, the energy deals under One Belt One Road umbrella will secure supplies needed by the Middle Kingdom as China's energy demand still continues to rise. Additionally, the land-based energy infrastructure can help to diversify energy import patterns. Finally, China will benefit from trade and currency swaps and reinforce the international power of the renminbi as a global trade currency. Deepening relationships with neighbours, expanding ties to major developing countries and building support for a reshaped international system all help PRC to build a network of nonWestern interdependencies with PRC in the centre of the picture.

The road to the bright future may become bumpy, though. The success of One Belt, One Road, especially in Post-Soviet space and in the Middle East, will depend on the cooperation of capricious regional and local leaders as they draw from vast experience of playing foreign powers off one another to gain personal political and financial advantage. It will also require Beijing to manage great power competition with Russia and the United States within Central Asia, South Asia, and the Middle East. In PostSoviet space particularly Russia's efforts to create a Eurasian Union and linking former Soviet states through economic cooperation, poses direct competition to China's own integration strategy. And despite the US troops withdrawing from Afghanistan and the United States' diminishing involvement in Central Asia, Chinese involvement across Eurasia will test Beijing's ability to balance competition with cooperation with both close neighbours and global political powers. This may put Chinese rhetoric of win-win outcomes and avoiding interference to a test. If Chinese actions go beyond the basic protection of its investments into broader geopolitical actions, international

29 S. Tiezzi, 'China's “New Silk Road” Vision Revealed', The Diplomat, 9 May 2014, at <http://thediplo mat.com/2014/05/chinas-new-silk-road-vision-revealed/>, 15 September 2015.

30 J. Stokes, 'China’s Road Rules', Foreign Affairs, 19 April 2015, at <https://www.foreignaffairs.com/ articles/asia/2015-04-19/chinas-road-rules>, 15 September 2015. 
perception of China's future foreign interventions could give credence to suspicions of Beijing's imperialistic desires.

The Post-Soviet space seems to signal first problems already. China's meteoric rise has hit the wall of the Post-Soviet local political patterns. All of the Central Asian states have already raised concerns about the structure of economic relationship with the Middle Kingdom, especially in terms of trade. They are a market for Chinese manufactured and consumer goods while their exports are overwhelmingly raw materials and energy. This is coupled with growing fears about Chinese economic intentions and expansion undermining traditional markets and distribution patterns. ${ }^{31}$ The impression is strengthened by the nature of non-assimilating Chinese migration, common violations of local regulations, especially concerning labour, as well as by the lack of respect for natural environment. ${ }^{32}$ Taking into consideration that Post-Soviet reality has already entangled and reshaped the plans of other international players, the progress of Chinese initiatives in the region may be a proving ground for their future success.

\section{MULTILATERALISM, THE POST-SOVIET SPACE AND THE WORLD WITHOUT THE WEST ${ }^{33}$}

In the midway of the second decade of the 21th century the Post-Soviet Space was shaken by three major developments. The annexation of Crimea may be perceived as a precedent in Russia's Post-Soviet foreign policy and more generally as a precedent in Post-Soviet relations as such. The general disappointment with colour revolutions and the on-going withdrawal of US forces from Afghanistan leaves the region with an impression of failed democratization and with an unanswered question about its future security. The PRC initiatives foretell growing Chinese Silk Road expansion according to different than Western or Russian terms and patterns. What is the meaning of the Russian show of hard power, Western step back and Chinese declarations of new patterns of integration for the Post-Soviet space? Is Crimea a sign of USSR revisionism? Is the West abandoning the scene? Is China taking over? Is it a time of power realignment? What are the outcomes of Great Powers' struggle in the Post-Soviet Space?

The answers cannot be straightforward. The major reason is the difference of perception of the Post-Soviet Space between each major player. Regardless how paradoxically it sounds, after a closer look the nature of Western and Chinese engagement in Post-Soviet space is to a large extent similar. Both parties were interested in the PostSoviet Space not because of any direct reason but rather because of a pressing need to stabilize the neighbouring regions, like Afghanistan, Xinjiang, and Eastern Europe.

31 'Go West, Young Chinaman: China and Central Asia', The Economist, 6 January 2007.

32 N. Kassenova, 'China as an Emerging Donor..., pp. 15-16.

33 N. Bartha, E. Ratner, S. Weber, 'Welcome to the World without the West', The National Interest, 12 November 2014, at <http://nationalinterest.org/feature/welcome-the-world-without-the-west-11651>, 15 September 2015. 
Thus, the Post-Soviet space was perceived as a function of other problems rather than as a centre of Western or Chinese policies. This was very different from the Russian perspective. As a former imperial power it has sought to play a dominant, privileged role. Regardless how much it is criticized by the Western commentators and politicians as representing neo-imperial ambitions, the Russian quest for renewed primacy in former USSR countries is not dissimilar to other historical, post-colonial powers, though. Soviet legacies, like the pipeline network, the linguistic and technical heritage, as well as other more recent developments, such as growing bilateral trade, more formalized security institutions and the millions of migrants who now earn their living and send valuable remittances back home, make the levers of power that Moscow wields still effective. ${ }^{34}$ However, the goal of maintaining a "privileged role” is difficult to measure. Unlike clearly defined objectives, concepts like privilege, status and prestige are social rankings and can be judged in relation to other actors. In consequence, Russia's own sense of status has tended to fluctuate as a function of its prevailing relations with other great players..$^{35}$ Accordingly, Russia's actual policies have been the function of its prevailing relationship with other great players and its broader efforts to assert itself in the multipolar world.$^{36}$ Crimea was no exception.

Some commentators state that the Kremlin conceived of the invasion and annexation of Crimea as a deliberate strike against the West, as well as Ukraine. President V. Putin apparently believes that he and Russia have more to gain from open confrontation with the United States and Europe - consolidating his political position at home and boosting Moscow's international stature - than from cooperation. ${ }^{37}$ This would foretell the comeback of Russian revisionism and a new march toward rebuilding USSR. Appearances are often deceptive, though. Moscow's repeated interventions in unstable regions of former Soviet states may have implied that the strategy of developing frozen conflicts managed by Russia has worked well. After closer inspection, each time Moscow has undermined the territorial integrity of a neighbouring state to maintain its influence there, in the long run the result has been quite opposite, though. Russian support for separatists in Azerbaijan, Georgia and Moldova has actually pushed all these states to seek a closer partnership with the West. The ffectiveness of Russian pressure on Central Asian states is also debatable. ${ }^{38}$ There are no reasons to expect that Ukraine will not follow a simi-

34 A. Cooley, Great Games..., p. 164.

35 C. Wallander, 'Russian Transimperialism and Its Implications', The Washington Quarterly, Vol. 30, No. 2 (2007), pp. 107-122, at <http://dx.doi.org/10.7551/mitpress/9780262622189.003.0013>.

36 A. Tsygankov, 'Preserving Influence in the Changing World: Russia's Grand Strategy', Problems of Post-Communism, Vol. 58, No. 2 (2011), pp. 28-44, at <http://dx.doi.org/10.2753/PPC1075-82 16580203>.

37 J. Mankoff, 'Russia's Latest..., pp. 65-66.

38 Kyrgyzstan and Tajikistan, the poorest states of the region are dependable on Moscow but Kazakhstan, the biggest oil exporter in the region, despite pressure to join Eurasian Community was able to develop stable export routes to Europe and China, which are independent from Russia. Uzbekistan constantly maneuvers between the West and the Russia, sometimes to the dismay of both of them. Turkmenistan, after gas war with Gazprom in 2008 was able to struck deals with China, what makes it 
lar trajectory. Annexation of Crimea and the threats of military intervention in eastern Ukraine have already pushed Kiev closer to Europe. ${ }^{39}$

It's also worth noticing that frozen conflicts and Crimea case are coincidental not only with the moments of internal instability of states targeted by Russia for intervention. They also imply that Russian influence was actually diminishing to an extent requiring hard power interference. ${ }^{40}$ Russia tried to base on Soviet references of responsibility to protect minority groups within Soviet and now Post-Soviet states. Looking at president's Putin popularity rise in Russia in 2008 (Georgia) and 2014 (Crimea) these moves certainly worked well domestically. From now independent Azerbaijani, Georgian, Moldovan or Ukrainian perspective these were actions designed to stop the move out of Russian sphere of influence, though. The Armenian - Azerbaijani war, in which Russia meddled, was coincidental with reestablishment of strong Armenian and Azeri consciousness, unrelated and to a certain degree unfriendly to Russia. Moldova - one of the Post-Soviet States most exposed to contacts with EU countries - was definitely moving westward and slowly abandoning cooperation with Moscow prior to Transnistria uprising. Georgia since regaining independence was consequently moving out of Russian sphere of influence. ${ }^{41}$ If one takes into account the emigration of Russian minority and the loosening of economic ties, the temporarily applied military strength was the only effective instrument of re-establishing Moscow's control available for Kremlin.

If we take the above observations into account, annexation of Crimea is a sign of weakness rather than of strength. Russia was not only unable to indirectly stop Ukraine from taking actions that may have been unfavourable for Moscow, like it was able to do during Leonid Kuchma and Victor Yanukovych days. It had to use direct force to destabilize the neighbouring state and to take over the control of one of the most important bases of Black Sea Fleet. If one takes into account that earlier temporary pressure was enough to achieve Russian goals this means not advance but deterioration of political potential.

Of course the year 2014 in Ukraine will work as a demonstration of Moscow's capability to directly threaten Post-Soviet neighbours. Certainly it will be a pain in the neck of all leaders of the nations of not only Post-Soviet space but more generally of the whole former Eastern Bloc. Surely, if Russia has shown once that it is still strong enough not to care about international judgment of its actions in its close neighbourhood, it

far less dependable on Russian pipelines. It is also worth remembering that none of these states legitimized Russian aggression in Georgia in 2008.

39 For example, the major reason of V. Yanukovych (former president of Ukraine) - opposition conflict: the agreement with EU, was signed immediately after the opposition took over the Power.

40 For background of Russian-Ukrainian relations after 1991: R. Solchanyk, Ukraine and Russia. The Post-Soviet Transition, Lanham 2000.

41 Even when ruled by E. Shevardnadze, the last Foreign Minister of the USSR, Georgia was politically active to minimize and eventually eliminate Russian presence on its territory, for example during Istanbul OSCE summit in 1999. More: P. Trzaskowski, Gruzińska "rewolucja róż." Zachód i idea Zachodu a przemiany polityczne w Gruzji, Warszawa 2009. 
would be unwise to assume that it will hesitate to do so again. But it is also worth noticing that it is not strong enough to re-establish its former control by drawing its neighbours voluntarily closer to itself than to other international centres. Despite still large potential to influence the short term international reality in the long run Russia is actually losing its ability to build durable alliances or developing stable cooperation. Crimea is not a sign of USSR's comeback. It is a sign of Russian the repertoire of international politics tools shrinking. ${ }^{42}$

The annexation of Crimea should not be interpreted as a beginning of ChineseRussian axis, either. From the Chinese perspective the Crimean case is actually a double edged sword. On one hand, it relates to a situation when a large regional power incorporates a territory of a smaller neighbour assumingly in the name of common ethnic ancestry. In the Chinese case this automatically brings Taiwan to mind. On the other hand, one should not forget that Russia annexed Crimea after, regardless if it was staged or not, a referendum. In the Taiwanese case from PRC's perspective, such a scenario was excluded already in the 1990s. And more broadly, for PRC a perspective of a minority voting itself out of a territory of a state it populates creates a disturbing picture in case of not only Taiwan but also of Xinjiang and Tibet. Thus, one may state that actually Crimean scenario should not be taken into account in case of Continental China.

However, even if the events in Ukraine are not to be repeated in China's immediate neighbourhood, the crisis of Russian - Western relations may still lead to reinvigoration of Russian-Chinese relations. Such a perspective is particularly tempting in the context of Russia being oil and gas exporting country while PRC is the world's largest importer of energy resources. There are just few rhetorical questions remaining - if this is the case why have Moscow and Beijing not cooperated earlier? Why there is just one oil pipeline from Russia to China, while numerous ones connect the Russian Federation with the West? And why the construction of the pipeline mentioned had to be negotiated for over a decade? ${ }^{43}$

Of course there is the case of colour revolutions of which both Russia and China were unequivocally critical. Despite the fact that 2003-2005 period marked the height of Sino-Russian cooperation, after a closer look even here the differences between Russia and China are significant. While Russia has perceived the changes as aimed against Moscow's privileged position in the Post-Soviet Space, China was concerned that democratization forces may spill over and destabilize Xinjiang. ${ }^{44}$ What was a challenge to Russian foreign policy, from the Chinese perspective was a threat to PRC's internal stability. As a result, Russia foreign policy took an anti-Western and an anti-democratic turn in cases of Georgia, Ukraine and Kyrgyzstan. China was satisfied with interpretation of Uyghur

42 Not mentioning economic problems involved. I. Berman, 'Paradise Lost in Crimea', Foreign Affairs, 8 September 2015, at <https://www.foreignaffairs.com/articles/ukraine/2015-09-08/paradise-lost-crimea>, 15 September 2015.

43 The negotiations were started by Yukos enterprise and abruptly after its owner M. Khodorkovsky arrest. More: G. Gleason, 'China, Russia and Central Asia: Triangular Energy Politics' in C.L. Currier, M. Dorraj, China's Energy Relations with the Developing World, New York 2011, pp. 83-100.

44 G. Bates, Rising Star. China's New Security Diplomacy, Washington 2010, pp. 25-35. 
separatism in terms of War on Terror and did not allow the stance on colour revolutions to spoil its relations with most of the international actors. Actually, from the Chinese perspective just like colour revolutions posed problems in the past, the frozen conflicts are posing problems in the future. AIIB, New Silk Road diplomacy and One Belt One Road initiatives are plans requiring stability. In case of every single frozen conflict the stability is a function of Russian political needs, which proved to be prone to many changes during first 25 years after the collapse of USSR. This does not seem to be a compelling perspective for long term cooperation between Beijing and Moscow. Thus, their alleged anti-democratic axis seems to be just an alliance of convenience.

Since the end of the Cold War Russia and China had not created an alternative to America-dominated world order. Actually, for all this time the West was more important economic partner for Russia and China than they were for each other. It's enough to note that most of the Russian oil and gas pipelines go to Western Europe and just one is going to China and to remind the Chinese - US financial lockdown. At the same moment the Moscow-Beijing cooperation was far more often disappointing than satisfying. Moscow is afraid of Chinese migration to Eastern Siberia and of growing Chinese presence in Central Asia. Beijing is disappointed with Russian inability to cooperate in large infrastructural and financial projects, not mentioning generally business-unfriendly Russian environment and Russian anti-Asian chauvinism. ${ }^{45}$

All this leads to a conclusion that if we focus too much on high-profile questions concerning competition for global leadership or challenging world order and primacy, we risk missing the nuances of political shifts currently underway in Post-Soviet space. ${ }^{46}$ The history of the region confirms that at times the agendas of the great players generated some flash points and tensions. This usually happened when one of the players gained a clear advantage and the equilibrium of political struggle clearly moved toward one side. ${ }^{47}$ However, in the long run it's impossible to give a straightforward

45 All these issues were visible during the Chinese-Russian summit in the middle of May 2014. The biggest achievement was an agreement to build "Power of Siberia" pipeline from Russia to China. Russia secured some $\$ 25$ billion in prepayment to finance the project which is important in context of Western sanctions. But it's worth noticing that Russia will supply natural gas at significantly lower prices than market rates. One should also remember that natural gas is making up less than $5 \%$ of Chinese energy mix and that China is able to immediately replace Russian supplies with Australian or Central Asian sources. Thus, despite the PR value of the summit for Russia, it's hard to call it a beginning of Alternative Power Axis in Asia. Instead it may foretell new future relations between US, Russia and China. As long as Moscow and Washington are locked in conflict, Beijing will use its position to maximize own opportunities at the expense of the other two players. More on PRC Energy Mix: 'Statistical Review of World Energy 2014', BP, at <https://www.bp.com/content/dam/bp/pdf/Energy-economics/statistical-review-2014/BP-statistical-review-of-world-energy-2014-full-report.pdf>, 14 September 2015, p. 27. More on PRC-Russian energy relations: P. Andrews-Speed, R. Dannreuther, China, Oil and Global Politics, London 2011 (Routledge Contemporary China Series, 68); K. Kozłowski, Geopolityka naftowa Chińskiej Republiki Ludowej [PRC Oil Geopolitics], Toruń 2013 (Biblioteka Azji i Pacyfiku).

46 An argument developed in: B. Gilley, A. O’Neil, 'Seeing Beyond Hegemony' in iidem (eds.), Middle Powers and the Rise of China, Washington 2014, pp. 237-258.

47 Particularly visible in the West-Russian relations' dynamics. T. Stępniewski, 'Cele rosyjskiej inwazji i okupacji na Ukrainie oraz reakcja Zachodu i Europy Środkowej', Rocznik Instytutu Europy Środkowo-Wschodniej, Vol. 12, No. 5 (2014), pp. 13-24. 
answer which party was the most successful in pursuing its goals in the Post-Soviet space. The current situation is still a function of all players' advances.

This leads to another conclusion. In a setting where several patrons or great powers vie for influence, their authority and influence is particularly diminished. The presence of several authority figures actually empowers their subordinates to shirk their individual commitments to any one patron, weakening the overall control of the objectively more powerful actors. ${ }^{48}$ To put it bluntly, great powers competition in PostSoviet space worked in favour of Post-Soviet states, or more precisely in favour of local regimes, and petrified the local imperatives rather than emanated any kind of comprehensive order or coherent long term process. Exclusively focusing on the objectives and interactions of the great powers neglects the considerable agency demonstrated by the Post-Soviet states in dealing with their geopolitical suitors. The rise of multiple regional patrons is empowering targeted governments to buck external pressures for political reforms of whatever kind. ${ }^{49}$

Simply applying the "divide and rule" argument to Soviet states fails to capture just how much the Soviet regime actually wanted to modernize and transform the Soviet states. Peculiar patterns of affirmative action favouring titular nations, mixed with the protection of national minorities, and with the development of Union-wide economic and administrative structures resulted in a distinct mix of imperial and state-building practices. As a result the Soviet and later the Post-Soviet regimes developed patrimonial patterns of managing political issues. The decades of independence did not introduce significant change in that respect. The local elites were provided with a new political context, opportunities and resources with which to consolidate their authority. They promoted the regime survival, used the state resources for private gain and acted as brokers between external actors and local constituencies. To a large extent they were reproducing the late Brezhnev era of a distinct political equilibrium, one in which Moscow tolerated local patrimonialism in exchange for stability and allegiance to the Union. ${ }^{50}$

After the collapse of the Soviet Union, Russia stayed the most powerful regional player by default rather than choice. In particular the colour revolutions have shown that the renewed external interest proved a political boon for all of the leaders of the Post-Soviet states. On one hand, many researchers share opinion that colour revolutions have developed a wide worldwide platform of social movements that will introduce democracy to the parts of the World where it was never expected. The organizers, mostly young people, share political experiences, know-how, coordinate their actions and play an increasingly important role in contemporary politics. On the other hand, the changes

48 C.S. Gray, 'Strategy and Culture' in T.G. Mahnken, D. Blumenthal (eds.), Strategy in Asia. The Past, Present, and Future of Regional Security, Stanford 2014, pp. 92-107.

49 Experience of color revolutions and of the backlash against them suggests that "indigenous democracy", inappropriate democratic ideals and cultural specificity can be cynically wielded by the elites to deflect criticism of their own shortcomings. A. Acharya, Whose Ideas Matter? Agency and Power in Asian Regionalism, Ithaca 2009, pp. 122-143 (Cornell Studies in Political Economy).

50 On patrimonialism and Brezhnev era: J. Willerton, Patronage and Politics in USSR, New York 1993 (Soviet and East European Studies, 82). 
brought by the colour revolutions seem to be very superficial. In Post-Soviet space, apart from Georgia, ${ }^{51}$ the colour revolutions did not establish a healthy democracy. There are justified reasons to ask the question were they a genuine explosion of popular demand for democracy or just an emanation of temporary weakness of authoritarian regimes. After all, most of the new political elites have made regime survival their overwhelming political imperative, were formulating domestic and foreign policies in order to maintain power, got entrenched in one-party patrimonial rule and were eliminating threats to their authority in a way similar to their predecessors. ${ }^{52}$ This allowed many of them to operate the state resources as a private property in a way leading to accumulation of individual power. Coupled with the ability to retain the role of intermediaries between their local constituencies and external patrons and suitors this opened the way to the practice of leveraging international engagement for domestic and economic gain. ${ }^{53}$ Today the same thing also seems to be the first challenge to Chinese expansion in the Post-Soviet space. Thus, the only lasting tendency in the Post-Soviet space was the progress of the process of de-camouflage of local patrimonial rules and practices.

\section{CONCLUSION}

25 years into the new power contest in the Post-Soviet space the political struggle continues and it is still hard to point clear winners and losers. Colour revolutions, frozen conflicts and the New Silk Road initiatives emanate the peaks of Russian, Western or Chinese influence. In the long run it's still hard to figure out who enjoys a clear advantage, though. The Western-Russian competition, best pictured by the clash of strategy based on frozen conflicts with colour revolutions empowered by the Western soft power, resulted in annexation of the Crimea and Eastern Ukraine stalemate - the deepest crisis since the end of the Cold War. The second decade of the 21th century seems to belong to PRC as it draws plans of re-establishing the ancient Silk Road in Eurasia but first clouds are already visible on the horizon. In the meantime a different set of actors Post-Soviet states - seem to gain ground.

Frozen conflicts, in particular in the case of Crimea, show Russia's paternalistic view of its Post-Soviet neighbours. During the 1990s Russian diplomacy used a term of "near abroad", since 2008 changed to "privileged interests" in regards to the Post Soviet space. ${ }^{54}$ It seems that the idea that Moscow has some special rights in regards to Post Soviet states still works well both among Russian public and Russian political elites. The reality shows that Russia is able to dominate only the relatively weakest Post-Soviet

51 However, also here the democratic character of M. Saakashvili regime is more and more often debated. K. Tsikhelashvili, Georgia Four Years after the Rose Revolution, 2 January 2008 (European Stability Initiative Report), at <http://www.esiweb.org/pdf/esi_turkey_tpq_id_109.pdf>, 15 September 2015.

52 P. Shishkin, Restless Valley. Revolution, Murder, and Intrigue in the Heart of Central Asia, London 2013, pp. 296-301.

53 A. Wilson, Ukraine Crisis..., pp. 144-160.

54 More on the issue of contemporary Russian diplomacy: J. Mankoff, Russian Foreign Policy... 
states like Kyrgyzstan, Tajikistan, Belarus or Armenia, though. The idea of customs union with Belarus and Kazakhstan proved to be easier to realize on paper than in practice and the Eurasian Union project after Crimea seems weakened. ${ }^{55}$

Colour revolutions were an emanation of Western expectations concerning the fourth wave of democratization. From the Western perspective, the beginning of the 21 th century was marked with its soft power success and promising regime changes, which were supposed to work in favour of US and EU interests. However, reality proved to be far from the black and white scenario presented in Western media. The revolutionaries turned to be increasingly autocratic and their regimes far more interested in enjoying power than in addressing their societies' needs. Eventually popular support for revolutions turned into a new wave of far more violent protests in 2007 in Georgia, 2010 in Kyrgyzstan and 2014 in Ukraine with no obvious gains for Western democracy supporters.

Finally, the New Silk Road diplomacy, the AIIB and the One Belt One Road initiative foretell Chinese ambitions to expand and project influence via the Post-Soviet Space. Bold plans of economic reanimation of the ancient Silk Road based on win-win strategies are designed to become a fundament of China's rise across Eurasia. Although still on paper, they slowly seem to raise as many expectations as concerns. The bumpy beginnings of the Chinese new norm and rising concerns about Chinese neo-colonial aspirations cast shadows over long term economic sustainability of the ambitious projects. Together with growing social fears of Chinese expansion this may pose a far more difficult obstacle for the PRC than the Russian or Western competition in the region.

All of the above observations lead to two general conclusions. First, the second decade of 21 th century is marked with growing Chinese influence in Post-Soviet Space. Second, the increase of Chinese role will probably be temporary as the local actors Post-Soviet states - will opt for cooperation with other powers to balance Beijing's influence, just as they did to balance Russian or Western aspirations.

A critical function of a leader has been to provide public goods to the region and, in particular, to play a stabilizing role in times of crisis. In that respect, Russia and the West have lost a lot of their potential. China's rise threatens to erode other powers influence not because Beijing has the appetite for a high-profile geopolitical battle, but because, at the ground level, China is providing short-term crisis lending development assistance and concessionary infrastructure financing. ${ }^{56}$ China's entry as an investor and aid donor is likely to undercut other donors and lending mechanisms. Until very recently Russia and Western actors exclusively discharged these public goods functions in the Post-Soviet Space. With alternative potential sources for aid, assistance and investment, the political leverage that derived from controlling the purse strings will continue to be diminished. Post-Soviet states in need of external funding and assistance have other options and will exercise them with greater frequency.

55 President Putin declared numerous times that the Union to develop a full potential should incorporate Ukraine. Now such a scenario is hard to imagine. A. Wilson, Ukraine Crisis..., pp. 183-204.

56 E.C. Economy, M. Levi, By All Means Necessary. How China's Resource Quest Is Changing the World, Oxford 2015, pp. 138-164. 
However, if one analyses the political situation in Post-Soviet space, one must not underestimate the independence of the Post-Soviet states. All the new republics remember well the years of Russian and Soviet hegemony. While historically dependent on Russia, when US and later China entered the region they have gained unprecedented political opportunities of winning one power against the other. One may say that an absolute success of Beijing, Washington or Moscow works against interests of Post-Soviet regimes as it narrows their sphere of action. They simply do not seem to be eager to give them up nor to exchange the old hegemon for a new one. Emerging multilateral reality of international relations and conflicting interests of the global players in the region gives them a lot of opportunities to exploit for good of their own national interests. The ability of regional elites to adapt to the great powers' struggles is a factor that should not be neglected in the analysis of the Post-Soviet space politics.

The Post-Soviet space is a perfect ground to analyse the dynamics of multilateralism. Over two decades of its history indicate that the key to understanding the region's politics is to abandon thinking about ways to dominate it but rather to look for advantages swinging the balance of power in one's favour. This definitely works in favour of patient Chinese expansion, is disadvantageous for overambitious Russia and very hard to understand for Western politicians. However, in the long run it means that none of the powers managed to develop a dominant position. The greatest winners in the struggle in the Post-Soviet space are the local regimes, which have learned how to manoeuvre between the great powers according to own needs. Unfortunately, quite often the biggest losers are the local societies which, as it became apparent in Kiev's Maidan in 2014, are misrepresented, if not forgotten in Post-Soviet political struggles.

\section{BIBLIOGRAPHY}

Acharya A., Whose Ideas Matter? Agency and Power in Asian Regionalism, Ithaca 2009 (Cornell Studies in Political Economy).

Andrews-Speed P., Dannreuther R., China, Oil and Global Politics, London 2011 (Routledge Contemporary China Series, 68).

Ash T.G., Snyder T., 'The Orange Revolution', New York Review of Books, 28 April 2005, at <http://www.nybooks.com/articles/archives/2005/apr/28/the-orange-revolution/>.

Bartha N., Ratner E., Weber S., 'Welcome to the World without the West', The National Interest, 12 November 2014, at <http://nationalinterest.org/feature/welcome-the-world-without -the-west-11651>.

Bates G., Rising Star. China's New Security Diplomacy, Washington 2010.

Berman I., 'Paradise Lost in Crimea', Foreign Affairs, 8 September 2015, at <https://www.foreignaffairs.com/articles/ukraine/2015-09-08/paradise-lost-crimea>.

'China, Kyrgyzstan Hold Joint Anti-Terrorism Exercise 10-11 October', Xinhua, 11 October 2002.

'China, Kyrgyzstan Plan Large-Scale Anti-Terrorism Exercise', AFP, 16 September 2002.

Collins K., Clan Politics and Regime Transition in Central Asia, Cambridge 2006. 
Cooley A., Great Games, Local Rules. The New Great Power Contest in Central Asia, New York 2012.

Economy E.C., Levi M., By All Means Necessary. How China's Resource Quest Is Changing the World, Oxford 2015.

Gavrilis G., The Dynamics of Interstate Boundaries, New York 2008 (Cambridge Studies in Comparative Politics).

Gilley B., O’Neil A., 'Seeing Beyond Hegemony' in iidem (eds.), Middle Powers and the Rise of China, Washington 2014.

Gleason G., 'China, Russia and Central Asia: Triangular Energy Politics' in C.L. Currier, M. Dorraj, China's Energy Relations with the Developing World, New York 2011.

'Go West, Young Chinaman: China and Central Asia', The Economist, 6 January 2007.

Gray C.S., 'Strategy and Culture' in T.G. Mahnken, D. Blumenthal (eds.), Strategy in Asia. The Past, Present, and Future of Regional Security, Stanford 2014.

Ikenberry G.J., 'The Illusion of Geopolitics', Foreign Affairs, Vol. 93, No. 3 (2014).Karrar H.H., The New Silk Road Diplomacy. China's Central Asian Foreign Policy since the Cold War, Vancouver 2009 (Contemporary Chinese Studies).

Kassenova N., 'China as an Emerging Donor in Tajikistan and Kyrgyzstan', Russie.Nei.Vissions, No. 36 (2009), at <http://www.ifri.org/en/publications/enotes/russieneivisions/ china-emerging-donor-tajikistan-and-kyrgyzstan $>$.

Keeran R., Kenny T., Socialism Betrayed. Behind the Collapse of the Soviet Union, New York 2010.

Kent A., Beyond Compliance. China, International Organizations and Global Security, Stanford 2007 (Studies in Asian Security).

Kozłowski K., Geopolityka naftowa Chinskiej Republiki Ludowej [PRC Oil Geopolitics], Toruń 2013 (Biblioteka Azji i Pacyfiku).

Kozłowski K., Państwo Środka a Nowy Jedwabny Szlak. Poradziecka Azja Centralna i Xinjiang w polityce CHRL [Middle Kingdom and the New Silk Road: the Post Soviet Central Asia and Xinjiang in PRC Politics], Torun 2011 (Biblioteka Azji i Pacyfiku).

Kuhn T.S., The Structure of Scientific Revolutions, Chicago 1996 (International Encyclopedia of Unified Science, 2, 2).

Lanteigne M., China and International Institutions. Alternative Paths to Global Power, New York 2005 (Asian Security Studies).

Lanteigne M., Chinese Foreign Policy. An Introduction, London 2009.

Mankoff J., 'Russia’s Latest Land Grab', Foreign Affairs, Vol. 93, No. 3 (2014).

Mankoff J., Russian Foreign Policy. The Return of Great Power Politics, Lanham 2011.

Marketos T.N., China's Energy Geopolitics. The Shanghai Cooperation Organization and Central Asia, Milton Park 2010 (Routledge Contemporary China Series).

Mead W.R., 'The Return of Geopolitics', Foreign Affairs, Vol. 93, No. 3 (2014).

Medeiros E.S., China's International Behavior: Activism, Opportunism and Diversification, Santa Monica 2009 (Rand Corporation Monograph Series).

'Peace Mission 2007', People's Daily, at <http://english.people.com.cn/90002/91620/index.html>. Polian P., Against Their Will. The History and Geography of Forced Migrations in the USSR, Budapest 2003.

Reid A., Borderland. A Journey through the History of Ukraine, Boulder 2000. 
'SCO to Hold Military Exercise on Fight Against Terrorism Late August', ITAR-TASS, 27 May 2003.

Shishkin P., Restless Valley. Revolution, Murder, and Intrigue in the Heart of Central Asia, London 2013.

'Sino-Russian Split at Regional Summit', The Asia Times, 15 November 2007, at <http://www. atimes.com/atimes/China/IK16Ad01.html>.

Solchanyk R., Ukraine and Russia. The Post-Soviet Transition, Lanham 2000.

'Statistical Review of World Energy 2014', BP, at <https://www.bp.com/content/dam/bp/ pdf/Energy-economics/statistical-review-2014/BP-statistical-review-of-world-energy2014-full-report.pdf>.

Stępniewski T., 'Cele rosyjskiej inwazji i okupacji na Ukrainie oraz reakcja Zachodu i Europy Środkowej', Rocznik Instytutu Europy Środkowo-Wschodniej, Vol. 12, No. 5 (2014).

Stępniewski T., 'Region Morza Czarnego w polityce Unii Europejskiej i Stanów Zjednoczonych Ameryki w XXI wieku' in J.M. Fiszer, P. Olszewski (eds.), System euroatlantycki w wielobiegunowym tadzie międzynarodowym, Warszawa 2013 (System Euroatlantycki w Wielobiegunowym Świecie i Jego Perspektywy, 6).

Stępniewski T., 'The Place of Central Asia in Poland's Foreign Policy', Roczniki Nauk Spotecznych KUL, Vol. 7 (43), No. 1 (2015).

Stokes J., 'China’s Road Rules', Foreign Affairs, 19 April 2015, at < https://www.foreignaffairs. com/articles/asia/2015-04-19/chinas-road-rules>.

Strayer R., Why Did the Soviet Union Collapse? Understanding Historical Change, London 1998.

Suny R., The Revenge of the Past. Nationalism, Revolution, and the Collapse of the Soviet Union, Chicago 1993.

Tiezzi S., 'China’s “New Silk Road” Vision Revealed', The Diplomat, 9 May 2014, at <http:// thediplomat.com/2014/05/chinas-new-silk-road-vision-revealed/>.

Trzaskowski P., Gruzińska "rewolucja róż". Zachód i idea Zachodu a przemiany polityczne w Gruzji, Warszawa 2009.

Tsikhelashvili K., Georgia Four Years after the Rose Revolution, 2 January 2008 (European Stability Initiative Report), at <http://www.esiweb.org/pdf/esi_turkey_tpq_id_109.pdf>.

Tsygankov A., 'Preserving Influence in the Changing World: Russia's Grand Strategy', Problems of Post-Communism, Vol. 58, No. 2 (2011), at <http://dx.doi.org/10.2753/ PPC1075-8216580203>.

Wallander C., 'Russian Transimperialism and Its Implications', The Washington Quarterly, Vol.30, No. 2 (2007), at <http://dx.doi.org/10.7551/mitpress/9780262622189.003.0013>.

Willerton J., Patronage and Politics in USSR, New York 1993 (Soviet and East European Studies, 82).

Wilson A., Ukraine Crisis. What It Means for the West, New Haven 2014.

Zhu Z., China's New Diplomacy. Rationale, Strategies and Significance, Burlington 2010.

Кара-Мурза С., Народное хозяйство СССР, Москва 2012.

Krzysztof KOZŁOWSKI, Doctor Habilitatus (Adam Mickiewicz University in Poznań, Poland) - associate professor at the Department of Political Studies, Collegi- 
um of Socio-Economics, Warsaw School of Economics. He is interested in the Central and East Asian politics, systemic change in the Post Soviet Space and economic analysis of organized crime. 